\title{
Perilaku Prososial ditinjau dari Kecerdasan Emosional Pada Siswa Kelas X SMA Swasta Sultan Iskandar Muda
}

\section{Prosocial Behavior Reviewed From Emotional Intelligence Of Tenth Grade Students In Sultan Iskandar Muda High School Medan}

\author{
Cherish Scorsinni(1)* ${ }^{*}$ Yulinda Septiani Manurung(2), Erick (3), July Chrystie Pasaribu (4) \\ Fakultas Psikologi, Universitas Prima Indonesia, Indonesia
}

Disubmit: 21 Oktober 2020; Diproses: 22 Oktober 2020; Diaccept: 22 November 2020; Dipublish: 01 Desember 2020 *Corresponding author: E-mail: cherishscorsinni@gmail.com

\begin{abstract}
Abstrak
Penelitian ini bertujuan untuk mengetahui adanya hubungan antara kecerdasan emosional dengan perilaku prososial pada siswa kelas X SMA Swasta Sultan Iskandar Muda Medan. Penilitian ini mengambil sampel menggunakan metode proporsi berstrata secara acak (proportionate stratified random sampling). Siswa-siswi SMA 1 Sultan Iskandar Muda merupakan populasi dalam penelitian ini serta sampel yang diambil berjumlah 161 siswa kelas X. Penelitian ini menggunakan metode kuantitatif, data penelitian dikumpulkan menggunakan skala perilaku prososial dengan 33 butir aitem dan skala kecerdasan emosional dengan 29 butir aitem. Uji asumsi yang digunakan yaitu uji normalitas dan uji linearitas. Data dianalisis menggunakan uji korelasi Pearson Product Moment dengan bantuan SPSS 21 for Windows. Hasil analisis data menunjukkan adanya hubungan positif antara kecerdasan emosional dengan perilaku prososial pada siswa kelas X SMA Swasta Sultan Iskandar Muda dengan koefisien korelasi Pearson Product Moment sebesar $\mathrm{R}=0.386$ dengan sig. 0.000 ( $\mathrm{p}<0.005)$. Dari perhitungan yang didapat dalam penelitian ini, diketahui bahwa perilaku prososial dipengaruhi oleh kecerdasan emosional (EQ) sebesar 14,9\% serta 85,1\% dipengaruhi oleh faktor lain yang tidak terkendali.
\end{abstract}

Kata Kunci: Kecerdasan Emosional; Perilaku Prososial

\begin{abstract}
The purpose of this study is to determine the existence of a correlation between prosocial behaviour in terms of emotional intelligence of tenth grade studentsofSultan Iskandar Muda Medan High School. The population in this study, amounting to a total of 296 students, are wholly the students of tenth grade Sultan Iskandar Muda Medan High School. While the samples taken were 161 students using the proportionate stratified random sampling method. This research utilizes quantitative methods, the research data are collected using a scale of prosocial behavior with 33 items and emotional intelligence scale with 29 items. The assumption test used consists of a normality test and a linearity test. Data were analyzed using Pearson Product Moment correlation test with the help of SPSS 21 for Windows. The result of the data analysis showed a positive correlation between emotional intelligence and prosocial behaviour in tenth grade students of Sultan Iskandar Muda High School with a Pearson Product Moment correlation coefficient of $R=0.386$ with sig. 0,000 ( $p<0.005)$. The results of the analysis also show that emotional intelligence provides an effective contribution of 14.9 percent to prosocial behavior and the remaining 85.1 percent is influenced by other factors not examined. Keywords: Emotional Intelligence; Prosocial Behaviour
\end{abstract}

Rekomendasi mensitasi :

Scorsinni, C., Manurung, S.Y., Erick., \& Pasaribu, C.J. 2020, Perilaku Prososial Ditinjau Dari Kecerdasan Emosional Pada Siswa Kelas X SMA Swasta Sultan Iskandar Muda. Jurnal Penelitian Pendidikan, Psikologi dan Kesehatan (JP3K), 1(3): 224-231. 


\section{PENDAHULUAN}

Pada dasarnya, manusia merupakan makhluk sosial, artinya manusia sebagai warga sosial tidak bisa hidup sendiri atau memenuhi kebutuhannya sendiri dalam kehidupan sehari-hari. Meskimemiliki status dan kekuasaan, manusia tetap akan membutuhkan bantuan orang lain. Dengan kata lain, setiap manusia cenderung akan berkomunikasi, berinteraksi, dan bersosialisasi dengan manusia lain (Nurrochim, Ridho dan Tumanggor, 2017)

Seiring dengan berjalannya waktu, kemajuan teknologi sangat mengalami perkembangan yang pesat. Dengan adanya kemajuan teknologi, banyak masyarakat yang semakin terikat dengan teknologi seperti smartphone dan hal tersebut membuat masyarakat semakin tidak acuh dengan apa yang terjadi pada lingkungan sekitar. Contohnya seperti ketika orang di sekitar sedang mengalami masalah ataupun bencana, tidak sedikit yang hanya melihat atau bahkan hanya meng- upload video pada mediasosial.

Pada hari Jumat, tanggal 22 Oktober 2019, sekitar waktu 16.05 WIB, terjadi sebuah peristiwa aksi bunuh diri yang dilakukan oleh seorang pemuda. Pemuda tersebut menjatuhkan dirinya dari atas gedung salah satu swalayan yang ada di Bandar Lampung. Namun yang memprihatinkan adalah sikap warga yang hanya melihat dan merekam aksi pemuda tersebut. Bahkan, ada seseorang pria yang merekam aksi tersebut dari dalam mobilnya sambil tertawa dan mengatakan 'loncat... loncat'. Dari kasus ini telah ditunjukkan bahwa kepedulian masyarakat dalam menolong tergolong rendah (Muslihah, 2019)
Berdasarkan hasil observasi dan wawancara yang dilakukan peneliti pada sekolah SMA Sultan Iskandar Muda, beberapa siswa-siswi tidak terlalu memiliki niat untuk membantu orang lain. Misalnya, ketika guru meminta bantuan untuk mengambilkan atau menaruh barang ke kantor guru, siswa-siswi tersebut cenderung tidak mau membantu dan kalaupun membantu kesannya terpaksa. Para siswa juga jarang mau membagi ilmu atau mengajarkan materi pembelajaran pada teman- temannya. Kasus-kasus di atas menunjukkan bahwa masih banyak orang yang tidak ingin ataupun berniat menolong orang lain. Salah satu perilaku prososial dapat ditunjukkan dengan menolong orang lain.

Perilaku prososial didefinisikan sebagai suatu tindakan melalui bantuan kepada orang lain walaupun Tindakan tersebut tidak memberikan manfaat secara langsung kepada yang bertindak (Hidayat and Bashori, 2016). Menurut Baron dan Byrne (dalam Hanurawan, 2018), perilaku prososial (prosocial behaviour) adalah perilaku yang member manfaat kepada orang lain. Istilah prososial berlaku bagi setiap perilaku di dalam memberikan bantuan kepada orang lain yang membutuhkan, dan perilaku tersebut tidak akan member manfaat secara langsung ketika perilaku tersebut dilakukan. Dalam hal ini bahkan dalam situasi-situasi tertentu perilaku membantu orang lain dapat memberikan resiko merugikan dalam diri seseorang.

Menurut Marrion(dalam Susanto, 2018), adapun aspek-aspek dalam perilaku prososial, yaitu berbagi/ memberi, bekerjasama, dan membantu. Aspek berbagi/ member terbagi menjadi 
berbagi waktu, berbagi materi, dan berbagi informasi. Aspek membantu terbagi menjadi menyelamatkan, membela, dan memindahkan penyebab. Aspek bekerjasama tidak terbagi menjadi subaspek yang lebih kecil. Terdapat banyak jenis perilaku prososial dalam kehidupan sehari-hari diantaranya adalah menolong, berbagi, kerjasama, menyumbang, dan memperhatikan kesejahteraan orang lain (Hidayat and Bashori, 2016).

Schroeder, Penner, Dovidio, dan Pilialvin (dalam Rahman, 2018) menyatakan bahwa perilaku prososial terbagi menjadi tiga sub-kategori, yaitu helping, altruism, dan cooperation. Helping dimaknai sebagai suatu tindakan yang memiliki konsekuensi memberikan keuntungan atau meningkatkan kualitas hidup orang lain (as an action that has the consequences of providing some benefit to or improving the well-being of another person). Altruism dimaknai sebagai jenis perilaku menolong dalam hal si penolong memberikan bantuan pada orang lain tanpa mengharapkan keuntungan (helping for cases in which the benefactor provides aid to another without the anticipation of rewards from externa lsources for providing assistance). Cooperation dimaknai sebagai suatu hubungan antara dua orang atau lebih yang saling bergantung secara positif karena tujuan tertentu (a correlation between two or more persons who are positively interdependent with respect to their goals).

Terdapat banyak faktor yang mempengaruhi perilaku prososial seseorang, salah satunya adalah kecerdasan emosional. Hasil penelitian Noya(2019) denganjudul "Hubungan
Kecerdasan Emosi dengan Perilaku Prososial Siswa di SMA Negeri 9 Halmahera Selatan" menunjukkan bahwa ada hubungan yang positif dan signifikan antara kecerdasan emosional dengan perilaku prososial.

Penelitian ini membuktikan bahwa kecerdasan emosional yang tergolong tinggi yang ada dalam individu, menunjukkan perilaku prososial yang tinggi terhadap orang lain. Goleman (dalam Hartono, 2012) mengartikan kecerdasan emosional menjadi suatu kesanggupan guna menghitung atau menyadari kondisi tempat kita sedang berada, agar dapat membaca emosi yang adad alam diri sendiri juga orang lain, serta mengambil tindakan yang tepat. Sedangkan menurut Muzaik (dalam Wahab, 2016), kecerdasan emosional ialah suatu kemampuan untuk mengenali, berekspresi, dan melakukan pengelolaan emosi kepada diri sendiri dan orang lain melalui tindakan konstruktif. Perilaku ini berupaya untuk bekerjasama dalam tim, yang melibatkan produktivitas daripada konflik.

Solvey (dalam Goleman, 2018) menempatkan kecerdasan pribadi Gardner dalam definisi dasar tentang kecerdasan emosional dan membaginya menjadi lima daerahutama, diantaranya kenali emosi diri, pengelolaan emosi, motivasi diri sendiri, kenali emosiyang ada dalam diri orang lain, serta membina hubungan. Menurut Solovey dan Mayer (Mashar, 2011), terdapat aspek-aspek yang di dalam kecerdasan emosional terbagi atas empati, mengungkapkan dan memahami perasaan, mengendalikan amarah, mandiri, kemampuan untuk menyesuaikan diri, menyukai, adanya 
kemampuan untuk memecahkan masalah pribadi, ketekunan, setiakawan, keramahan, dan sikap hormat. Lima unsur yang dimiliki kecerdasan emosiya itu adanya kesadaran diri (self-awareness), adanya pengaturan diri (self-regulation), motivasi (motivation), empati (empathy), dan keterampilan sosial (social skills) (Helmawati, 2018)

Maghfiroh(2017) pernah melakukan penelitian mengenai "Hubungan antara Kecerdasan Emosional dengan Perilaku Prososial Siswa Di SMP Negeri 2 Sidoarjo". Hasil penelitian membuktikan bahwa ada hubungan signifikan yang positif antara kecerdasan emosional terhadap perilaku prososial seseorang. Penelitian ini menunjukkan bahwa seseorang mampu menunjukkan perilaku prososial yang tinggi apabila memiliki kecerdasan emosional yang tinggi begitu pula sebaliknya.

Berdasarkan uraian di atas, maka peneliti tertarik untuk melakukan penelitian dengan judul "Perilaku Prososial ditinjau dari Kecerdasan Emosional pada Siswa SMA Sultan Iskandar Muda." Penelitian ini bertujuan untuk menguji dan mengetahui pengaruh kecerdasan emosional terhadap perilaku prososial seseorang. Hipotesis penelitian yang diajukan adalah adanya hubungan positif antara kecerdasan emosional terhadap perilaku prososial. Adapun rumusan masalah dalam penelitian ini yaitu (1) Apakah ada hubungan kecerdasan emosional terhadap perilaku prososial? (2) Bagaimana hubungan kecerdasan emosional terhadap perilaku prososial?

Penelitian ini bertujuan untuk mengetahui hubungan antara kecerdasan emosional terhadap perilaku prososial. Adapun manfaat dari penelitian ini yaitu, manfaat teoritis diharapkan dapat memberikan sumbangan kepada ilmu psikologi dan manfaat praktis bagi para siswa diharapkan dapat menunjukkan perilaku prososial terhadap orang lain dan lingkungan sekitar dan bagisekolah juga diharapkan dapat membantu meningkatkan kesadaran para siswa agar dapat meningkatkan kecerdasan emosional serta perilaku prososial.

\section{METODE PENELITIAN}

Variabel dalam penelitian ini menggunakan 2 variabel yaitu, perilaku prososial sebagai variable terikat $(\mathrm{Y})$ dan kecerdasan emosional (EQ) sebagai variable bebas (X). Variabel terikat adalah diduga sebagai variable yang diduga sebagai akibat atau yang dipengaruhi oleh variabel yang mendahuluinya, yaitu variable bebas sedangkan variable bebas adalah variabel yang menentukan atau yang mempengaruhi adanya variabel yang lain (Soewadji, 2012).

Menurut Martono (2011), populasi adalah seluruh objek atau subjek di suatu wilayah yang memiliki syarat-syarat tertentu yang berhubungan dengan penelitian, atau keseluruhan unit atau individu yang ada di dalam lingkup penelitian. Populasi dari sampel yang digunakan dalam penelitian ini ialah seluruhan anak didik kelas X di SMA Swasta Sultan Iskandar Muda Medan yang berjumlah 296 siswa.

Metode pengambilan sampelnya yaitu Proportionate Stratified Random Sampling. Martono (2011) menyatakan bahwa proportionate stratified random sampling merupakan teknik pengambilan 
sampel yang dilakukan ketika atribut atau elemen dalam populasi tidak seragam dan dikelompokkan secara proporsional. Menurut Sugiyono(2018), sampel merupakan sebagian dari jumlah dan karakteristik yang dimiliki populasi tersebut. Sampel dalam penelitian ini ialah semua siswa kelas X SMA Sultan Iskandar Muda dengan jumlah 161 siswa berdasarkan tabel Isaac \& Michael dengan taraf kesalahan 5\%.

Penelitian ini menggunakan metode kuantitatif yang bersifat korelasional. Pengumpulan data menggunakan skala perilaku prososial dan skala kecerdasan emosional. Pada skala perilaku prososial, variable diukur berdasarkan aspek periaku prososial yang dikemukakan oleh Marrion (dalam Susanto, 2018), yaitu berbagi/ memberi, bekerjasama dan membantu. Skala ini terdiri dari 48 aitem pernyataan yang terbagi menjadi 24 butir aitem favorable dan 24 butir aitem unfavorable.

Skala kecerdasan emosional terdiri dari 50 butir aitem yang terbagi menjadi 25 butir aitem favorable dan 25 butir aitem unfavorable. Variabel ini diukur berdasarkan aspek kecerdasan emosional yang dikemukakan Solvey(dalam Goleman, 2018), yaitu mengenali emosi diri, mengelola emosi, memotivasi diri sendiri, mengenali emosi orang lain, serta membina hubungan.

Alat ukur yang berupa skala perilaku prososial dan skala kecerdasan emosional harus terlebih dahulu diuji validitas dan reliabilitas sebelum digunakan untuk mengambil data penelitian. Arikunto (2013) menyatakan bahwa validitas adalah suatu ukuran yang menunjukkan peringkat-peringkat kesahihan atau validasi suatu instrument. Reliabilitas merupakan sesuatu instrumen dapat dipercaya untuk digunakan sebagai alat pengumpul datakarena instrumen tersebut sudah baik. Teknik Alpha Cronbach adalah Teknik yang digunakan dalam penelitian untuk menguji reliabilitas.

Sebelum dilakukan analisa data, terlebih dahulu melakukan uji asumsi, yakni uji normalitas dan linearitas. Dalam penelitian ini, teknik korelasi Pearson Product Moment adalah teknik analisis data yang digunakan dengan tujuan untuk menguji korelasi antara perilaku prososial dan kecerdasan emosional yang dimiliki oleh para siswa. Menurut Martono(2011), korelasi Pearson atau yang sering disebut dengan korelasi product moment merupakan alat uji statistik yang digunakan untuk menguji hipotesis asosiatif (uji hubungan) dua variabel. Analisis data akan diolah dengan bantuan SPSS versi 21.

\section{HASIL DAN PEMBAHASAN}

Metode analisis korelasi pearson product moment adalah metode analisis data yang digunakan dalam metode ini dengan menggunakan bantuan SPSS Statistic 21 for Windows. Metode ini digunakan untuk mencari dan mengetahui pengaruh kecerdasan emosional terhadap perilaku prososial pada siswa kelas $\mathrm{X}$ Sekolah Swasta Sultan Iskandar Muda.

Analisis menggunakan teknik korelasi Pearson Product Moment. Berdasarkan hasil analisis diperoleh nilai Pearson Correlation sebesar 0.386 dengan Sig sebesar $0.000(\mathrm{p}<0.05)$. Hal tersebut menunjukkan adanya korelasi positif antara variable kecerdasan emosional 
dengan perilaku prososial dan dikategorikan memiliki korelasi yang sedang. Dari hasil ini maka dapat dinyatakan bahwa terdapat hubungan positif antara kecerdasan emosional terhadap perilaku prososial pada siswa kelas X SMA Sultan Iskandar Muda. Berikut table hasil uji korelasi Pearson Product Moment.

Tabel 1. Uji Korelasi Pearson Product Moment

\begin{tabular}{lll}
\hline Analisis & $\begin{array}{l}\text { Pearson } \\
\text { Correlation }\end{array}$ & $\begin{array}{l}\text { Signifikansi } \\
(\mathrm{p})\end{array}$ \\
\hline Korelasi & .386 & 0.000 \\
\hline
\end{tabular}

Berdasarkan tabel 2, tampak bahwa nilai R Square $=0.149$. Dari nilai tersebut dapat disimpulkan bahwa kecerdasan emosional memberikan sumbangan efektif sebesar 14,9 persen terhadap perilaku prososial dan sisanya 85,1 persen dipengaruhi oleh faktor lain yang tidak diteliti.

Tabel 2. Sumbangan Efektif (Modal Summary)

\begin{tabular}{lllll}
\hline Model & $R$ & $\begin{array}{l}R \\
\text { Square }\end{array}$ & $\begin{array}{l}\text { Adjusted } \\
\text { R Square }\end{array}$ & $\begin{array}{l}\text { Std. Error } \\
\text { of the } \\
\text { estimate }\end{array}$ \\
\hline 1. & .386 & .149 & .144 & 4.708 \\
\hline
\end{tabular}

Penelitian yang dilaksanakan pada 161 siswa kelas X SMA Sultan Iskandar Muda Medan memperoleh hasil bahwa ada hubungan positif kecerdasan emosional terhadap perilaku prososial dengan koefisien korelasi Pearson Product Moment sebesar R = 0.386 dengan Sig. 0.000 ( p < 0.05), dengan sumbangan efektif kecerdasan emosional sebesar 14,9 persen mempengaruhi perilaku prososial. Hal ini menunjukkan bahwa semakin tinggi kecerdasan emosional seseorang maka semakin tinggi pula perilaku prososial yang dimiliki dan semakin rendah kecerdasan emosional seseorang maka perilaku prososialnya akan semakin rendahpula.

Individu yang memiliki kecerdasan emosional yang tinggi akan menunjukkan perilaku prososial dalam kehidupan sehari-hari, salah satunya kesediaan untuk menolong orang lain agar dapat lebih meringankan beban orang lain yang Kemampuan individu untuk dapat bekerjasama juga menunjukkan bahwa individu tersebut memiliki kecerdasan emosional yang tinggi. Individu yang dapat berbagi perasaan terhadap orang lain dalam keadaan duka maupun suka juga menunjukkan bahwa individu tersebut memiliki rasa kepedulian yang tinggi terhadap lingkungan sekitarnya dan orang lain. Hal ini sejalan dengan wawancara yang dilakukan pada guru BK Sultan Iskandar Muda yang menyatakan bahwa beberapa siswa bersedia untuk membantu ketika diminta bantuan yakni ketika diminta untuk mengambil ataupun menaruh sesuatu di kantor. Para siswa juga menunjukkan rasa empati dan kepedulian terhadap sesama siswa. Hal tersebut terlihat ketika ada siswa yang mengalami musibah, para siswa secara inisiatif memberi bantuan secara fisik ataupun dengan memberi semangat. Hal tersebut dikarenakan petinggi di sekolah tersebut sering melakukan kegiatan amal serta menunjukkan kepedulian terhadap sesama yang menyebabkan para siswa di sana terpengaruh untuk melakukan hal yang sama.

Barr dan Hirgins (dalam Lestari and Witri, 2019) menyatakan bahwa perilaku prososial muncul dipengaruhi oleh efek kepedulian sosial dan menemukan bahwa 
kekhawatiran emosional berhubungan positif untuk membantu perilaku prososial. Ini menunjukkan bahwa rasa kepedulian yang dimiliki oleh individu secara emosional akan membentuk perilaku prososial yang baik dalam diri.

Penelitian ini juga sejalan dengan

hasil penelitian Husada (2013) menunjukkan bahwa kecerdasan emosional berpengaruh secara positif terhadap perilaku prososial pada remaja di SMP Cita Hati Surabaya, nilai positif tersebut menunjukkan bahwa adanya pengaruh meningkatnya kecerdasan emosional terhadap meningkatnya perilaku prososial individu. Pada penelitian Noija dan Astuti (2015) pada pelajar SMA Negeri 10 Yogyakarta juga menunjukkan bahwa terdapat pengaruh positif dan signifikan antara kecerdasan emosional terhadap perilaku prososial.

Hasil tersebut sesuai dengan pendapat Batson (dalam Sabiq dan Djalali, 2012) yang menyatakan bahwa berdasarkan beberapa penelitian mengenai perilaku prososial, menemukan adanya hubungan antara perilaku prososial dengan kecerdasan emosional (EQ) terutama pada aspek empati. Ini menunjukkan bahwa orang dengan empati yang tinggi cenderung akan menolong orang lain atau menunjukkan perilaku prososial dan juga sebaliknya. Arbdiati (dalam Sabiq dan Djalali, 2012) menyatakan bahwa individu dengan EQ memiliki kemampuan untuk mempersepsikan emosi, mengelola dan menggunakan emosi dengan tepat, sehingga dapat memfasilitasi kehidupan sebagai pribadi yang bersosialisasi.

Berdasarkan hasil uraian di atas, dapat disimpulkan bahwa terdapat hubungan positif antara kecerdasan emosional terhadap perilaku prososial. Kecerdasan emosional penting dimiliki oleh individu dalam menghadapi berbagai hal, serta rasa kepedulian yang tinggi terhadap lingkungan sekitar merupakan komponen penting dalam perilaku prososial.

\section{SIMPULAN}

Kesimpulan yang dapat ditarik dilihat dari data yang dikumpulkan selama penelitian yaitu terdapat pengaruh positif kecerdasan emosional terhadap perilaku prososial. Hal tersebut terlihat dari hasil perhitungan pearson correlation dengan nilai koefisien korelasi sebesar 0.386 dan $\mathrm{p}=0.000$ serta faktor kecerdasan emosional berpengaruh terhadap perilaku prososial sebesar $14,9 \%$.

\section{DAFTAR PUSTAKA}

Arikunto, S. (2013) Prosedur Penelitian: Suatu Pendekatan Praktik. Jakarta: Rineka Cipta.

Goleman, D. (2018) Emotional Intelligence. Jakarta: PT Gramedia Pustaka Utama.

Hanurawan, F. (2018) Psikologi Sosial Terapan Untuk Pemecahan Masalah Perilaku Sosial. Depok: Rajawali Pers.

Hartono, A. (2012) EQ Parenting. Jakarta: PT Gramedia Pustaka Utama.

Helmawati (2018) Mendidik Anak Berprestasi Melalui 10 Kecerdasan. Bandung: PT Remaja Rosdakarya.

Hidayat, K. and Bashori, K. (2016) Psikologi Sosial. Jakarta: Erlangga.

Husada, A. (2013) 'Hubungan Pola Asuh Demokratis Dan Kecerdasan Emosi Dengan Perilaku Prososial Pada Remaja', Persona:Jurnal Psikologi Indonesia, 2(3), pp. 266-277

Lestari, S. S. and Witri, T. M. (2019) 'Hubungan antara Religiusitas dan Kecerdasan Emosional Terhadap Komunikasi Sosial ( Studi Pada Perilaku Prososial Mahasiswa )', Medium:Jurnal Ilmiah Fakultas Ilmu Komunikasi Universitas Islam Riau, 7(1), pp. 1-17.

Maghfiroh, R. L. (2017) 'Hubungan antara kecerdasan emosional dengan perilaku prososial siswa di smp negeri 2 sidoarjo', 
Kajian Moral dan Kewarganegaraan, 5(01), pp. 196-210.

Martono, N. (2011) Metode Penelitian Kuantitatif. Jakarta: PT Raja Grafindo Persada.

Mashar, R. (2011) Emosi Anak Usia Dini dan Strategi Pengembangannya. Jakarta: Kencana.

Muslihah, E. (2019) Bukannya Mencegah, Beberapa Orang Rekam Aksi Bunuh Diri Pemuda di Lampung. Available at: https://regional.kompas.com/read/2019/0 2/22/20500431/bukannya-mencegahbeberapa-orang-rekam-aksi-bunuh-diripemuda-di-lampung.

Noija, M. D. A. and Astuti, K. (2015) 'Hubungan Antara Kecerdasan Emosional Dan Internal Locus of Control Dengan Perilaku Prososial Pada Pelajar Di Sma Negeri 10 Yogyakarta', Insight: Jurnal Ilmiah Psikologi, 17(2), p. 128

Noya, A. (2019) 'Hubungan Kecerdasan Emosi Dan Perilaku Prososial', Jurnal Penelitian dan Pengembangan Pendidikandan Pengembangan Pendidikan, 2(1), pp. 28-34.

Nurrochim, Ridho, K. and Tumanggor, R. (2017) Ilmu Sosial dan Budaya Dasar. Jakarta: Kencana.

Rahman, A. A. (2018) Psikologi Sosial Integritasi Pngetahuan Wahyu dan Pengetahuan Empirik. Jakarta: PT Raja Grafindo Persada.

Sabiq, Z. and Djalali, M. (2012) 'Kecerderdasan Emosi, Kecerdasan Spiritual dan Perilaku Prososial Santri Pondok Pesantren Nasyrul Ulum Pamekasan', Persona:Jurnal Psikologi Indonesia, 1(2), pp. 53-65

Soewadji, J. (2012) Pengantar Metodologi Penelitian. Jakarta: Penerbit Mitra Wacana Media.

Sugiyono (2018) Metodologi Penelitian Kuantitatif, Kualitatif, dan R\&D. Bandung: Penerbit Alfabeta.

Susanto, A. (2018) Bimbingan dan Konseling di Sekolah Konsep, Teori dan Aplikasinya. Jakarta: Prenamedia Group.

Wahab, R. (2016) Psikologi Belajar. Jakarta: Rajawali Pers. 